\title{
Role of Speech-Language Pathologist in Pediatric Corrosive Ingestion in Zagazig University Children Hospital \\ Hatem Mohammed Hussein ${ }^{1}$, Hossam Fathy El-saadany ${ }^{1}$, Elham Magdy Hafiz ${ }^{2}$, Mahmoud Gamal-eldeen Mohamed Mohamed ${ }^{1 *}$ \\ ${ }^{1}$ Department of Pediatrics, Faculty of Medicine, Zagazig University \\ ${ }^{2}$ Department of Phoniatrics, Faculty of Medicine, Zagazig University \\ * Corresponding author: Mahmoud Gamal-eldeen Mohamed Mohamed, Mobile: (+20)01020430873, \\ E-mail: M.g.abasy@gmail.com
}

\section{ABSTRACT}

Background: Pediatric corrosive ingestion injuries represent a significant proportion of total ingestion injury annually. Medical and surgical advancements over the past five decades led to significant reductions in mortality. Optimal treatment of children with ingestion injuries requires a multi-skilled team approach.

Objective: The aim of the work was to assess the effects of corrosive ingestion in children and to determine the role of speech-language pathologist. Patients and methods: This cross section study was conducted on 52 patients with corrosive ingestion. The patients were admitted at Zagazig University Children Hospitals from February 2018 to February 2019. Results: Our results showed that there was high significant relation between impaired oral intake and period of admission, PICU admission, days to initiate oral feeding and grade of mucosal injury. Also, there was high significant relation between fluid, semisolid and solid dysphagia and oropharyngeal mucosal injury. Also, there was a high significant relation between oesphageal mucosa grading of injury and oropharyngeal mucosal injury. Conclusion: Children admitted to hospital with severe ingestion injury to the oral cavity, oropharynx and esophagus had significant and sustained delay in the recovery of effective PO intake milestones, with many requiring ongoing gavage feeding at hospital discharge.

Keywords: Speech-Language Pathologist, Pediatric Corrosive Ingestion.

\section{INTRODUCTION}

Children who ingest liquid chemical substances sustain diffuse injuries to multiple sites across the oral cavity, pharynx, larynx and eosophagus (1). The pediatric population is the most affected. The highest risk age groups are infants and pre-schoolers (2). Although, it is not a public health problem, caustic ingestion is a significant issue worldwide, particuralry in developing countries in which an unsafe environment is a substantial risk factor for child injury ${ }^{(3)}$.

Dysphagia and difficulty with oral intake are common initial symptoms following ingestion injury in children. More than one third of children have difficulty with oral intake within 48 hours following injury, so swallowing assessment is needed to detect which stage of swallowing is affected ${ }^{(4)}$. Endoscopic grading of mucosal injury: $0=$ normal examination, $\mathrm{I}=$ edema and hyperemia of the mucosa, IIa = superficial ulceration, erosions, friability, blisters, exudates, hemorrhages, and whitish membranes, IIb $=$ grade IIa plus deep discrete or circumferential ulcerations, IIIa $=$ small scattered areas of multiple ulceration and areas of necrosis with brownblack or grayish discoloration, and IIIb = extensive necrosis (5). Severe injuries and associated complications that often involve children or health professionals are initiated by cessation of oral intake, as well as long-term nonoral feeding, with gavage feeding often used to avoid further damage to tissues in the short term ${ }^{(6)}$.

There is no standard treatment of caustic ingestion during the acute phase. Several treatment strategies are described in pediatric surgery books ${ }^{(7)}$.

All patients who suffered a caustic ingestion should be hospitalized and evaluated comprehensively.
The clinical history must emphasize the type and amount of caustic and if possible get the product package. Hemodynamic stabilization and adequacy of the patient's airway are priorities. The induction of vomiting or gastric lavage is contraindicated following caustic ingestion because a re- exposure of the oesophageal mucosa to the caustic agent with further injury may occur ${ }^{(8)}$.

\section{AIM OF THE WORK}

The aim of the work was to assess the effects of corrosive ingestion in children and to determine the role of speech-language pathologist.

\section{PATIENTS AND METHODS}

\section{Study design and setting:}

This cross section study was conducted on 52 patients with corrosive ingestion. The patients were admitted at Zagazig University Children Hospitals from February 2018 to February 2019.

Ethical approval and written informed consent: An approval of the study was obtained from Zagazig University Academic and EthicalCommittee. Every patient signed an informed written consent for acceptance of the treatment.

\section{Patients were subjected to the following:}

A) Full history taking including: Name, age, sex, length of admission, need for and duration of pediatric intensive care unit (PICU) admission, need for intubation/ventilation, substance ingested (nature, 
amount, $\mathrm{Ph}$ ), location of ingestion event (home, other) and symptoms on presentation to hospital.

\section{B) General and local examination:}

* Examination of the oral cavity which may reveal hyperemia, edema or ulcerations.

* General examination including searching for concomitant skin burn to other body parts.

* Consultation of toxicologist and cardiothoracic pediatric surgeon.

\section{C) Fibro-optic endoscopic evaluation of swallowing (FEES):}

The patients underwent FEES by the speechlanguage pathologist during the period of acute admission 1-7 days from ingestion injury.

Both naris were examined visually and the scope passed through the most patent naris without administration of a topical anesthetic or vasoconstrictor to the nasal mucosa, thereby eliminating any potential adverse anesthetic reaction.

All foods/liquids were dyed green with food coloring:

* Liquid consistency: 3, 5, 10, 20 ml water colored with food dye

* Semi-solid consistency: teaspoon of yoghurt colored with food dye

* Solid consistency: Dry bread or biscuits, which were dipped in colored liquid.

\section{Findings of FEES examination included:}

* Pharyngeal mucosa, which my reveal hyperemia, edema or ulceration

* Pharyngeal phase of swallowing of fluid, semi-solid and solid substances, which may reveal normal or residual and chocking (Figure 1, 2 and 3).

According to these findings: The speech-language pathologist organize the feeding therapy including period of admission, days-post injury to initiate oral feeding and feeding status during period of admission, after discharge and days post-injury to the resumption of normal oral intake.

The speech-language pathologist also follow up the patients before and after eosophagoscopy

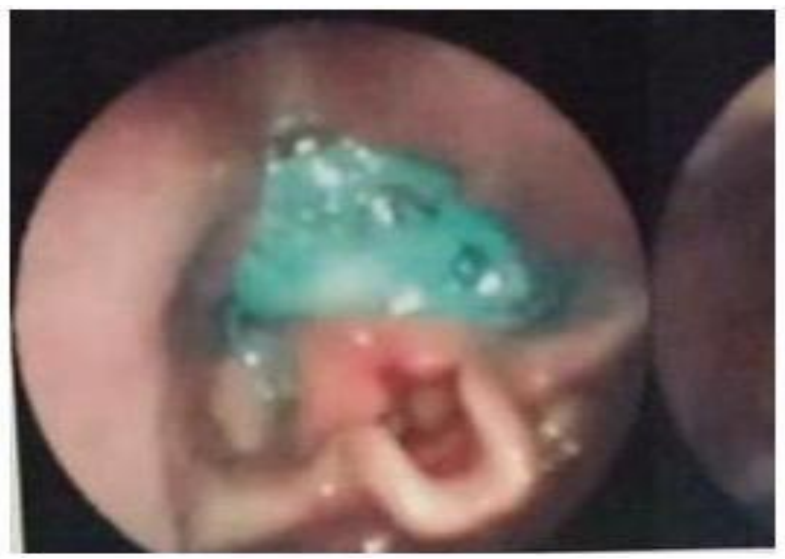

Figure (1): Residual during fluid swallowing.

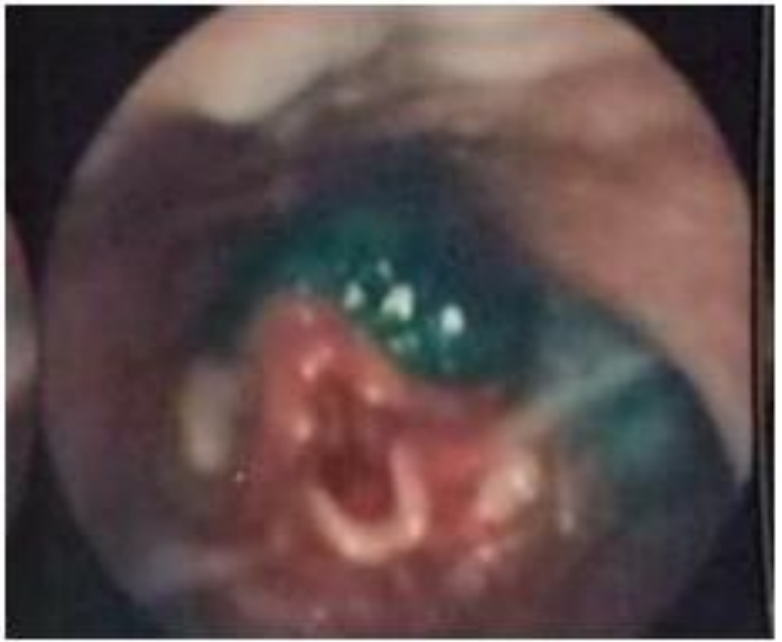

Figure (2): Residual during semi-solid swallowing.

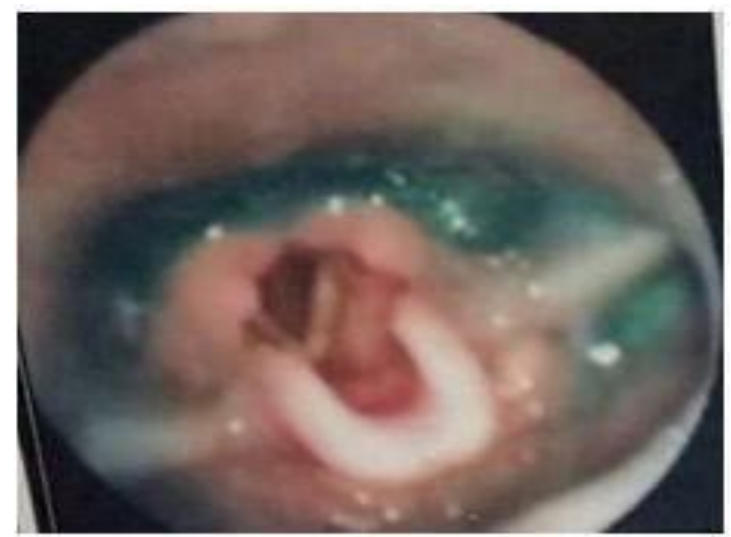

Figure (3): Residual during solid swallowing.

\section{D) Esophagoscopy:}

The patients were under general anesthesia, always administered by a certified pediatric anesthesiologist anesthesia. We use flexible endoscope (Figure 4).

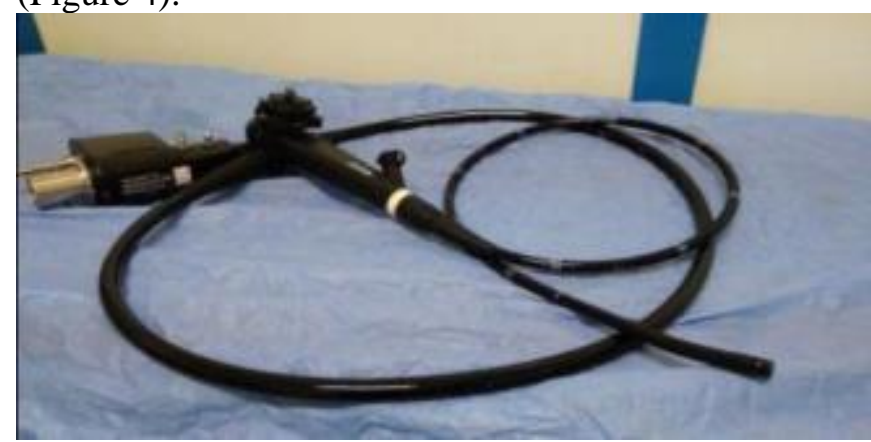

Figure (4): Pentax 8.7 flexible endoscope.

Findings of Esophagoscopy included:

1) Grading of esophageal mucosal injury:

* 0: normal examination.

* I: edema and hyperemia of the mucosa.

* IIa: superficial ulceration erosions, friability, blisters, exudates, hemorrhages, and whitish membranes.

* IIb: grade IIa plus deep discrete or circumferential ulcerations.

* IIIa: small scattered areas of multiple ulceration and areas of multiple necrosis with brown-black or grayish discoloration.

* IIIb: extensive necrosis ${ }^{(5)}$. 


\section{2) Esophageal stricture}

Esophagoscopy was used to detect level, site, size, number of esophageal strictures for further dilatation.

\section{Esophageal dilatation:}

We used Savary-Gilliard dilator (flexible and directed plastic dilators), first passing a flexible metallic guidewire through the stricture until reaching thestricture and then passing a different caliber Savary dilators $(7, \quad 9, \quad 11$ and $12.8 \quad \mathrm{~mm})$ (21FR,27FR,33FR,38FR) depending on the diameter of the stricture segment. Most subsequent dilation procedures were scheduled in 2 weeks until achievement of intraluminal dilatation of the esophagus $(12.8 \mathrm{~mm})$, improvement in patient's symptoms or earlier if patients returned with further dysphagia. After each dilation patients were observed for 4 hours with specific attention to the occurrence of chest pain, abdominal pain and difficulty in breathing and hemodynamic status. Patients were discharged home the same day with instructions to immediately report the development of fever, chest pain or shortness of breath. All patients received antireflux therapy for 1week (10 mg of omeprazole after endoscopic examination).

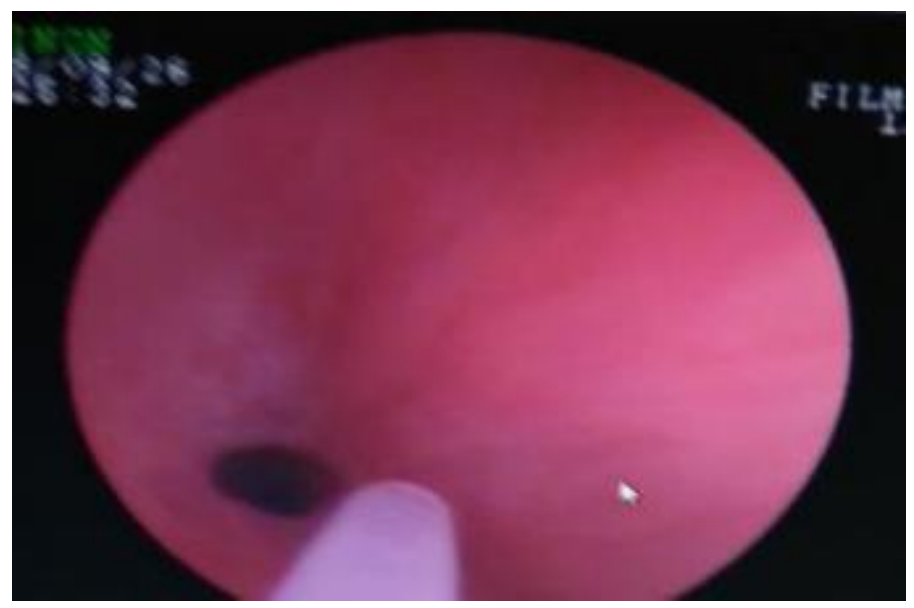

Figure (5): The stricture part

During the follow up for next 6 months, number of dilations needed by the patient, size of $1^{\text {st }}$ dilator, clinical symptom (vomiting and dysphagia) and weight were registered for each patient.

\section{Statistical analysis}

Recorded data were analyzed using the statistical package for social sciences, version 20.0 (SPSS Inc., Chicago, Illinois, USA). Quantitative data were expressed as mean \pm standard deviation (SD). Qualitative data were expressed as frequency and percentage. The following tests were done:

- Independent-samples t-test of significance was used when comparing between two means.

- Chi-square $\left(\mathrm{x}^{2}\right)$ test of significance was used in order to compare proportions between two qualitative parameters.
- The confidence interval was set to $95 \%$ and the margin of error accepted was set to $5 \%$. The p-value was considered significant as the following:

- Probability (P-value)

- P-value $<0.05$ was considered significant.

- P-value $<0.001$ was considered as highly significant.

- P-value $>0.05$ was considered insignificant.

\section{RESULTS}

Table (1): Demographic data of the studied cases:

\begin{tabular}{|l|c|c|}
\hline Variable & \multicolumn{2}{|c|}{$36.2 \pm 7.4$} \\
\hline Age (months) \\
\hline $\begin{array}{l}\text { Mean } \pm \text { SD } \\
\text { Range }\end{array}$ & \multicolumn{2}{|c|}{$18-50$} \\
\hline \multicolumn{2}{|c|}{ No. } & $\%$ \\
\hline Sex & 25 & 48.1 \\
\hline Female & 27 & 51.9 \\
Male &
\end{tabular}

This table showed that the mean age of cases was $36.2 \pm 7.4$ with range of (18-50) months and percent of females was $48.1 \%$ and males was $51.9 \%$.

Table (2): Swallowing pattern of the studied cases

\begin{tabular}{|l|c|c|}
\hline Variable & N & \% \\
\hline Swallowing & & \\
Semisolid & 37 & 71.2 \\
Normal & 15 & 28.8 \\
Shocking & & \\
\hline Swallowing Solid & & \\
Normal & 45 & 86.5 \\
Shocking & 7 & 13.5 \\
\hline Swallowing Fluid & & \\
Normal & 33 & 63.5 \\
Shocking & 19 & 36.5 \\
\hline
\end{tabular}

This table showed that normal swallowing of semisolid fluid in $71.2 \%$ of cases, solid in $86.5 \%$ of cases and fluid in $57.7 \%$ of cases.

Table (3): Characters of stricture of the studied cases

\begin{tabular}{|l|c|c|}
\hline Variable & $\mathbf{N = 5 2}$ & $\mathbf{\%}$ \\
\hline Stricture location: & & \\
-Lower 1/3 & 6 & 11.5 \\
-Middle 1/3 & 8 & 15.4 \\
-Upper 1/3 & 27 & 51.9 \\
-Whole esophagus & 5 & 9.6 \\
-No stricture & 6 & 11.5 \\
\hline Stricture segment: & & \\
Short & 36 & 69.2 \\
Long & 10 & 19.2 \\
No stricture & 6 & 11.5 \\
\hline
\end{tabular}

This table showed that stricture location was in upper segment by a percent of $58.7 \%$, lower segment by a percent of $13 \%$, milddle segment by a percent of $17.4 \%$ and whole esophagus by a percent of $10.9 \%$. stricture segment was short in $69.2 \%$, long in $19.2 \%$ and no stricture in $11.5 \%$. 
Table (4): Dysphagia Improvement after dilatation

\begin{tabular}{|l|c|c|}
\hline Disphagia & & \\
Improvement after & & \\
dilatation: & 41 & $\mathbf{7 8 . 8}$ \\
-Improved & $\mathbf{5}$ & $\mathbf{9 . 6}$ \\
-still complaining & $\mathbf{6}$ & $\mathbf{1 1 . 6}$ \\
- No stricture & & \\
\hline
\end{tabular}

This table showed that $78.8 \%$ of cases showed dysphagia improvement after dilatation in comparison to $9.6 \%$ that showed no improvement.
Table (5): Stricture improvement after dilatation

\begin{tabular}{|l|l|l|}
\hline Stricture & & \\
Improvement & & \\
after dilatation: & $\mathbf{3 0}$ & $\mathbf{5 7 . 8}$ \\
-Improved & $\mathbf{1 6}$ & $\mathbf{3 0 . 6}$ \\
-still need & $\mathbf{6}$ & $\mathbf{1 1 . 6}$ \\
dilatation & & \\
- No stricture & & \\
\hline
\end{tabular}

This table showed that $57.8 \%$ of cases showed stricture improvement after dilatation in comparison to $30.6 \%$ of cases who still need for dilatation.

Table (6): Relation between dysphagial improvement after endoscopy of the studied cases and nature of ingested substance

\begin{tabular}{|c|c|c|c|c|c|c|}
\hline \multirow[t]{2}{*}{ Variable } & \multicolumn{2}{|c|}{$\begin{array}{l}\text { Improved cases } \\
\mathrm{N}=41\end{array}$} & \multicolumn{2}{|c|}{$\begin{array}{l}\text { Not improved cases } \\
\mathrm{N}=5\end{array}$} & \multirow[t]{2}{*}{$\chi^{2}$} & \multirow[t]{2}{*}{$P$ value } \\
\hline & $\mathrm{N}$ & $\%$ & $\mathrm{~N}$ & $\%$ & & \\
\hline \multicolumn{7}{|c|}{ Substance ingested : } \\
\hline $\begin{array}{l}\text { Cloride } \\
\text { Flash } \\
\text { Potash }\end{array}$ & $\begin{array}{l}9 \\
6 \\
26\end{array}$ & $\begin{array}{l}22.0 \\
14.6 \\
63.4\end{array}$ & $\begin{array}{l}0 \\
2 \\
3\end{array}$ & $\begin{array}{l}0.0 \\
40.0 \\
60.0\end{array}$ & 2.75 & 0.252 \\
\hline \multicolumn{7}{|c|}{ Liquid nature : } \\
\hline $\begin{array}{l}\text { Acid } \\
\text { Alkali }\end{array}$ & $\begin{array}{l}15 \\
26\end{array}$ & $\begin{array}{l}36.6 \\
63.4\end{array}$ & $\begin{array}{l}2 \\
3\end{array}$ & $\begin{array}{l}40.0 \\
60.0\end{array}$ & Fisher test & 0.618 \\
\hline
\end{tabular}

$\chi^{2}$ is for chi square test

$\mathrm{p}$ value is significant if $<0.05$

This table showed that there was no significant relation between outcome after endoscopy of the studied cases and nature of ingested substance.

Table (7): Relation between impaired oral intake and Period of admission, PICU admission, days to initiate oral feeding and grade of mucosal injury

\begin{tabular}{|c|c|c|c|c|c|c|}
\hline Variable & \multicolumn{2}{|c|}{$\begin{array}{c}\text { Impaired oral } \\
\text { intake } \\
\mathrm{N}=19\end{array}$} & \multicolumn{2}{|c|}{$\begin{array}{c}\text { Normal oral intake } \\
\qquad \mathbf{N}=33\end{array}$} & MW & P value \\
\hline \multicolumn{7}{|c|}{ Period of hospital admission (days) : } \\
\hline $\begin{array}{l}\text { Mean } \pm \text { SD } \\
\text { Median } \\
\text { Range }\end{array}$ & \multicolumn{2}{|c|}{$\begin{array}{c}8.4 \pm 8 \\
5 \\
1-25 \\
\end{array}$} & \multicolumn{2}{|c|}{$\begin{array}{c}22 \pm 10.9 \\
30 \\
10-30\end{array}$} & 23.0 & $\begin{array}{l}<0.05 \\
(\mathbf{S})\end{array}$ \\
\hline \multicolumn{7}{|c|}{ Days to initiate oral feeding : } \\
\hline $\begin{array}{l}\text { Mean } \pm \text { SD } \\
\text { Median } \\
\text { Range }\end{array}$ & \multicolumn{2}{|c|}{$\begin{array}{c}2.88 \pm 1.8 \\
1.5 \\
1-3\end{array}$} & \multicolumn{2}{|c|}{$\begin{array}{c}3.6 \pm 0.54 \\
3.5 \\
2-7\end{array}$} & 18.0 & $\begin{array}{c}<0.001 \\
\text { (HS) }\end{array}$ \\
\hline & $\mathrm{N}$ & $\%$ & $\mathrm{~N}$ & $\%$ & $\chi^{2}$ & $P$ value \\
\hline \multicolumn{7}{|c|}{ PICU admission: } \\
\hline $\begin{array}{l}\text { Yes } \\
\text { No }\end{array}$ & $\begin{array}{c}1 \\
18\end{array}$ & $\begin{array}{c}5.3 \\
94.7\end{array}$ & $\begin{array}{l}11 \\
22\end{array}$ & $\begin{array}{l}33.4 \\
66.6\end{array}$ & Fisher test & $\begin{array}{l}<0.05 \\
(\mathbf{S})\end{array}$ \\
\hline \multicolumn{7}{|c|}{ Grade of eosophageal mucosal injury: } \\
\hline $\begin{array}{l}0 \\
\text { I } \\
\text { Пa } \\
\text { Пb } \\
\text { Ша } \\
\text { Шb }\end{array}$ & & & & & & $\begin{array}{c}<0.001 \\
\text { (HS) }\end{array}$ \\
\hline
\end{tabular}

MW is for Mann whitney test.

This table showed that there was high significant relation between impaired oral intake and period of admission and PICU admission. Also, there was significant relation between impaired oral intake and days to 
initiate oral feeding. Also, there was signifivant relation between impaired oral intake and grade of mucosal injury.

Table (8): Relation between oropharyngeal mucosa and swallowing

\begin{tabular}{|c|c|c|c|c|c|c|c|c|}
\hline \multirow[t]{2}{*}{ Variable } & \multicolumn{2}{|c|}{$\begin{array}{l}\text { Edema } \\
\mathrm{N}=10\end{array}$} & \multicolumn{2}{|c|}{$\begin{array}{l}\text { Hyperemia } \\
\text { N=27 }\end{array}$} & \multicolumn{2}{|c|}{$\begin{array}{l}\text { Sloughing } \\
\mathrm{N}=15\end{array}$} & \multirow[t]{2}{*}{$\chi^{2}$} & \multirow[t]{2}{*}{$P$ value } \\
\hline & $\mathrm{N}$ & $\%$ & $\mathrm{~N}$ & $\%$ & & & & \\
\hline \multicolumn{9}{|l|}{ Solid } \\
\hline $\begin{array}{l}\text { Chocking } \\
\text { Normal }\end{array}$ & $\begin{array}{l}4 \\
6\end{array}$ & $\begin{array}{l}40.0 \\
60.0\end{array}$ & $\begin{array}{l}0 \\
27\end{array}$ & $\begin{array}{l}0.0 \\
100.0\end{array}$ & $\begin{array}{l}3 \\
12\end{array}$ & $\begin{array}{l}20.0 \\
80.0\end{array}$ & 10.79 & $\begin{array}{l}\mathbf{0 . 0 0 5} \\
\text { (S) }\end{array}$ \\
\hline \multicolumn{9}{|l|}{ Semisolid } \\
\hline $\begin{array}{l}\text { Chocking } \\
\text { Normal }\end{array}$ & $\begin{array}{l}4 \\
6\end{array}$ & $\begin{array}{l}40.0 \\
60.0\end{array}$ & $\begin{array}{l}0 \\
27\end{array}$ & $\begin{array}{l}0.0 \\
100.0\end{array}$ & $\begin{array}{l}11 \\
4\end{array}$ & $\begin{array}{l}73.3 \\
26.7\end{array}$ & 26.01 & $\begin{array}{l}<0.001 \\
\text { (HS) }\end{array}$ \\
\hline \multicolumn{9}{|l|}{ Fluid } \\
\hline $\begin{array}{l}\text { Chocking } \\
\text { Normal }\end{array}$ & $\begin{array}{l}3 \\
7\end{array}$ & $\begin{array}{l}30.0 \\
70.0\end{array}$ & $\begin{array}{l}1 \\
26\end{array}$ & $\begin{array}{l}3.7 \\
96.3\end{array}$ & $\begin{array}{l}11 \\
4\end{array}$ & $\begin{array}{l}73.3 \\
26.7\end{array}$ & 23.28 & $\begin{array}{l}<0.001 \\
\text { (HS) }\end{array}$ \\
\hline
\end{tabular}

$\chi^{2}$ is for chi square test

This table showed that there was high significant relation between semisolid, fluid and solid dysphagia and oropharyngeal mucosal injury.

Table (9): Relation between oropharyngeal mucosa and oesophageal mucosa grading

\begin{tabular}{|c|c|c|c|c|c|c|c|c|}
\hline \multirow[t]{2}{*}{ Variable } & \multicolumn{2}{|c|}{$\begin{array}{l}\text { Edema } \\
\mathrm{N}=10\end{array}$} & \multicolumn{2}{|c|}{$\begin{array}{l}\text { Hyperemia } \\
\mathrm{N}=27\end{array}$} & \multicolumn{2}{|c|}{$\begin{array}{l}\text { Sloughing } \\
N=15\end{array}$} & \multirow[t]{2}{*}{$\chi^{2}$} & \multirow[t]{2}{*}{ P value } \\
\hline & $\mathrm{N}$ & $\%$ & $\mathrm{~N}$ & $\%$ & & & & \\
\hline \multicolumn{9}{|c|}{ Oesphageal mucosa grading of injury : } \\
\hline 0 & 0 & 0.0 & 4 & 14.8 & 0 & 0.0 & \multirow[t]{6}{*}{45.05} & \multirow{6}{*}{$\begin{array}{l}<0.001 \\
\text { (HS) }\end{array}$} \\
\hline I & 5 & 50.0 & 15 & 55.6 & 2 & 13.3 & & \\
\hline Па & 5 & 50.0 & 2 & 7.4 & 3 & 20.0 & & \\
\hline$\Pi b$ & 0 & 0.0 & 0 & 0.0 & 3 & 20.0 & & \\
\hline Ша & 0 & 0.0 & 0 & 0.0 & 2 & 13.3 & & \\
\hline Шb & 0 & 0.0 & 0 & 0.0 & 5 & 33.4 & & \\
\hline
\end{tabular}

$\chi^{2}$ is for chi square test

This table showed that there was high significant relation between oesphageal mucosa grading of injury and oropharyngeal mucosal injury.

Table (10): Relation between oropharyngeal mucosa and hospital admission, days to initiate oral feeding and PICU admission

\begin{tabular}{|c|c|c|c|c|c|c|c|c|}
\hline Variable & \multicolumn{2}{|c|}{$\begin{array}{l}\text { Edema } \\
\mathrm{N}=10\end{array}$} & \multicolumn{2}{|c|}{$\begin{array}{l}\text { Hyperemia } \\
\mathrm{N}=27\end{array}$} & \multicolumn{2}{|c|}{$\begin{array}{l}\text { Sloughing } \\
\mathrm{N}=15\end{array}$} & $\mathbf{F}$ & $P$ value \\
\hline \multicolumn{9}{|c|}{ Days of hospital admission : } \\
\hline $\begin{array}{l}\text { Mean } \pm \\
\text { SD }\end{array}$ & \multicolumn{2}{|c|}{$9.60 \pm 7.35$} & \multicolumn{2}{|c|}{$5.77 \pm 7.21$} & \multicolumn{2}{|c|}{$15.60 \pm 10.40$} & 16.93 & $<0.001(\mathrm{HS})$ \\
\hline \multicolumn{9}{|c|}{ Days to initiate oral feeding: } \\
\hline Mean \pm & \multicolumn{2}{|c|}{$3.30 \mathrm{v} \pm 1.41$} & \multicolumn{2}{|c|}{$1.78 \pm 0.97$} & \multicolumn{2}{|c|}{$4.60 \pm 1.80$} & 23.26 & $<0.001(\mathrm{HS})$ \\
\hline & $\mathrm{N}$ & $\%$ & $\mathrm{~N}$ & $\%$ & $\mathrm{~N}$ & $\%$ & $\chi^{2}$ & P value \\
\hline \multicolumn{9}{|c|}{ PICU admission : } \\
\hline $\begin{array}{l}\text { Yes } \\
\text { No }\end{array}$ & $\begin{array}{l}2 \\
8\end{array}$ & $\begin{array}{l}20.0 \\
80.0\end{array}$ & $\begin{array}{l}5 \\
2 \\
2\end{array}$ & $\begin{array}{l}18.5 \\
81.5\end{array}$ & $\begin{array}{l}5 \\
10\end{array}$ & $\begin{array}{l}33.3 \\
66.7\end{array}$ & 1.25 & 0.533 \\
\hline
\end{tabular}

F is for Kruskal Wallis test

This table showedd that there was high significant relation between oropharyngeal mucosa and hospital admission and days to initiate oral feeding, while there was no significant relation between oropharyngeal mucosa and PICU admission. 


\section{DISCUSSION}

The present study included 52 child with mean age of cases is $36.2 \pm 7.4$ months with range of (18-50) months and percent of females was $48.1 \%$ and males was $51.9 \%$.

Tarek et al. ${ }^{\left({ }^{9}\right)}$ whose study was observational study that included 100 children with an established diagnosis of post-corrosive oesophageal stricture who were engaged in repeated endoscopic dilatation sessions and conducted at the Paediatric Endoscopy Unit, Cairo University Paediatric Hospital from March 2015 to September 2016. They found that males represented $63 \%$ of the patients. The mean age of the patients was $5.9 \pm 2.6$ years. Similarly Yalçın and Aygün (10) in their study reported that of 45 cases, 24 $(53.3 \%)$ were males, while $21(46.7 \%)$ were females. The youngest case was 9 months old, the oldest case was 168 months and average age of the cases was 24.7 months. Follent et al. ${ }^{(11)}$ who conducted their study in a quaternary hospital in Brisbane, Australia, for the acute care management of a chemical or button battery ingestion injury during a 6-year period (January 2008December 2013). They found that mean age was 31.5 \pm 35.4 months and percent of females was $49 \%$ and males was $51 \%$. Temiz et al. ${ }^{(12)}$ found that the male/female ratio was $129 / 77$ and mean age was 38.1 \pm 28.8 months.

Children, especially boys, have well-developed skills and are curious to examine substances and drink them. However, they lack the knowledge of the portability of substances. This implies that boys in preschool stage (3-4 years) need more attention and caring by parents to avoid such ingestion incidents. Moreover, parents' behaviors are affected further by culture $^{(13)}$.

In this study percents of ingested substances were $19.2 \%, 15.4 \%$ and $65.4 \%$ for chloride, flash and potash respectively. Also $34.6 \%$ of liquids were acidic and $65.4 \%$ were alkaline. Moreover, $92.3 \%$ of cases ingested the substance at home and $7.7 \%$ of cases in other places. This was quiet similar to what stated by Tarek $\boldsymbol{e t} \boldsymbol{a l} .{ }^{(9)}$ who demonstrated that the majority of their patients ingested an alkaline substance (potash). $6 \%$ of them ingested a neutral substance (chlorine) and only $4 \%$ of them ingested an acidic substance $\left(\mathrm{H}_{2} \mathrm{SO}_{4}\right)$. Nondela et al ${ }^{(14)}$ reported that the majority of ingested caustic substance $(27.5 \%)$ was the oxidizing/reducing agent in the form of household bleach and all these had low-grade oesophageal injury. None of them subsequently developed oesophageal strictures. The second most common caustic substances ingested was strong alkaline in either liquid, crystal or powder form, with $\mathrm{pH}$ varying from 9 to 13. Liquid alkaline ingestions caused the most severe injury with three developing oesophageal strictures. Acid ingestion was infrequently seen in three children (7.5\%) and none of these developed long-term oesophageal injury. Yalçın and Aygün ${ }^{(\mathbf{1 0})}$ reported that their cases were exposed to bleacher in 20 patients $(44.4 \%)$, dishwasher detergent in 11 patients $(24.4 \%)$, rinse aid in 5 patients $(11.1 \%)$, drain cleaner in 4 patients $(8.9 \%)$, washing machine detergent in 3 patients $(6.7 \%)$, decalcifier in 1 patient $(2.2 \%)$ and surface cleaner (sodium hypochlorite) in 1 patient $(2.2 \%)$. This comes in consistency with what stated by Follent et al. ${ }^{(11)}$ who demonstrated that percents of ingested substances were $65 \%, 29 \%$ and $3 \%$ for alkali, button battery and unknown respectively. $78 \%$ of cases ingested the substance at home. In a study by Huang et al. ${ }^{(15)}$ conducted in Australia, they reported that $76 \%$ of the accidents occurred at home, where $74 \%$ were caused by alkaline, $6 \%$ by acidic agents, and $20 \%$ were caused by contamination with other agents.

Follent et al. ${ }^{(11)}$ stated that at discharge, 10/31 children $(32 \%)$ in the impaired PO intake cohort were NPO ( 9 with gavage, and 1 recieving TPN), 1 child was receiving gavage with some $\mathrm{PO}$ intake (thin fluids, soft diet), 15/31 (48\%) were managing full modified PO intake ( 2 on clear fluids only, 8 on soft diet and 5 on puree diet) and $5(16 \%)$ had returned to regular premorbid PO diet.

We also observed that there was edema in oropharyngeal mucosa in $19.2 \%$, hyperemia in $51.9 \%$ and sloughing in $28.8 \%$. Grading of oesophageal mucosa was grade 0 in $7.7 \%$, grade $\mathrm{I}$ in $42.3 \%$, grade $\Pi$ a in $19.2 \%$, grade $\Pi b$ in $5.8 \%$, grade Шa in $3.8 \%$ and $\amalg b$ in $9.7 \%$ and no endoscopy in $11.5 \%$. Nondela et al. ${ }^{(14)}$ verified that $67.5 \%$ of children were found to have grade 0 , I and IIa on endoscopic oesophageal injury grading. Follent et al. (11) observed that grading of injury was grade 0 in $4 \%$, grade I in $16 \%$, grade $\Pi$ a in $43 \%$, grade $\Pi \mathrm{b}$ in $22 \%$, grade $Ш$ in $10 \%$ and no endoscopy in $6 \%$. A study by Tohda et al. ${ }^{(16)}$ from the United States, over 28-year period, reported 95 patients with caustic ingestion. Approximately $60 \%$ of the patients had a mild degree (grade 1) or no esophageal injury (grade 0 ) and only $15 \%$ had grade 3 injury. Temiz et al. ${ }^{(12)}$ observed that grading of injury was grade 0 in $41.7 \%$, grade I in $23.8 \%$, grade $\Pi$ a in $20.4 \%$, grade $\Pi b$ in $13.6 \%$, grade Ша in $0.5 \%$ and no endoscopy in $6 \%$.

In this study, stricture location was in upper segment by a percent of $58.7 \%$, lower segment by a percent of $13 \%$, milddle segment by a percent of $17.4 \%$ and whole esophagus by a percent of $10.9 \%$. Stricture segment was short in $69.2 \%$, long in $19.2 \%$ and no stricture in $11.5 \%$. Tarek et $\boldsymbol{a l} .{ }^{(9)}$ in their study verified that stricture location was in upper segment by a percent of $87.1 \%$, lower segment by a percent of $3.5 \%$, middle segment by a percent of $62.4 \%$. Stricture segment was short in $30.6 \%$, long in $69.4 \%$ and no stricture in $11.5 \%$. 
Our study verified that $1^{\text {st }}$ dilator size was $7 \mathrm{~mm}$ in $32.7 \%$ of cases and $9 \mathrm{~mm}$ in $55.8 \%$ of cases. While, $3^{\text {rd }}$ dilator size was $11 \mathrm{~mm}$ in $19.2 \%$ of cases and 13 $\mathrm{mm}$ in $28.8 \%$ of cases. Number of dilatations was 5 time in $17.3 \%$ of cases, 6 times in $36.5 \%$ of cases, 7 times in $7.7 \%$ of cases and 8 or more in $26.9 \%$ of cases. On contrary, Tarek et al. ${ }^{(9)}$ illustrated that number of dilatations was $35.21 \pm 12.79$. Tharavej (17) performed stepwise dilatation from a 5-mm to a 7-, 9, 11-, 12.8-, 14-, and 15-mm diameter. The "rule of three" was applied in each session.

Kochman et al. ${ }^{(2)}$ defined refractory benign esophageal stricture (RBSE) and recurrent stricture as an inability to successfully dilate to a $14-\mathrm{mm}$ diameter over five sessions at 2-week intervals and the inability to maintain luminal patency for more than 4 weeks after successful 14-mm dilatation, respectively.

We also observed that $78.8 \%$ of cases showed dysphagia improvement after dilatation in comparison with $9.6 \%$ that showed no improvement. Also In the current study $57.8 \%$ of cases showed stricture improvement after dilatation in comparison with $30.6 \%$ of cases who still need for dilatation. Tharavej (17) observed that two patients with recurrent stricture after adequate dilatation who refused surgery underwent long-term periodic repeated dilatation at 12-week intervals (four sessions/year). They were satisfactory with the treatment and had good swallow function and nutritional status without the need of enteral feeding. Contini $\boldsymbol{e t}$ al. ${ }^{(3)}$ agree with us where they reported a good nutritional status is strongly related to a successful dilatation of esophageal stricture.

Singhal and Kar ${ }^{(6)}$ recommended endoscopic esophageal dilatation as a standard primary treatment of corrosive esophageal stricture. The treatment efficacy is comparable between the balloon and bougie techniques.

A study from India by Broor et al. ${ }^{(17)}$ that included patients with accidental ingestion and stricture length $<2 \mathrm{~cm}$, reported a success rate for dilatation of $>80 \%$

In this study we found that there was no significant relation between outcome after endoscopy of the studied cases and nature of ingested substance.

There was high significant relation between impaired oral intake and period of admission and PICU admission. Also, there was significant relation between impaired oral intake and days to initiate oral feeding. Besides, there was significant relation between impaired oral intake and grade of mucosal injury. There was high significant relation between semisolid, fluid and solid dysphagia and oropharyngeal mucosal injury. There was high significant relation between oesophageal mucosa grading of injury and oropharyngeal mucosal injury.
There was high significant relation between oropharyngeal mucosa and hospital admission and days to initiate oral feeding while there was no significant relation between oropharyngeal mucosa and PICU admission. This is in agreement with what stated by Follent et al. ${ }^{(11)}$ who stated that children who had more oropharyngeal mucosal injury with impaired PO intake, had significantly more severe endoscopicgraded esophageal injuries grade II and III injuries, which were more likely to have a PICU admission and had longer hospital stays than children with nonimpaired PO intake.

Yet long term follow up was needed to assess late onset complications and the role of endoscopy on long term evaluation, another limitation to our study was need for evaluating factors affecting success of dilatation. In conclusion, children admitted to hospital with severe ingestion injury to the oral cavity, oropharynx, and esophagus had significant and sustained delay in the recovery of effective PO intake milestones, with many requiring ongoing gavage feeding at hospital discharge. Feeding therapy provided by the speech-language pathologist may provide the opportunity to improve patient safety, support return to a developmentally appropriate PO diet, and improve quality of life for children with ingestion injury, and their families.

\section{CONCLUSIONS}

Children admitted to hospital with severe ingestion injury to the oral cavity, oropharynx, and esophagus had significant and sustained delay in the recovery of effective PO intake milestones with many requiring ongoing gavage feeding at hospital discharge. Feeding therapy provided by the speechlanguage pathologist may provide the opportunity to improve patient safety, support return to a developmentally appropriate PO diet and improve quality of life for children with ingestion injury and their families.

\section{RECOMMENDATION}

Speech-language pathology should be considered in children corrosive ingestion as an adjuvant treatment plan to dialatation therapy. Further studies involving larger sample size and longer follow up period are essential to confirm or refuse our findings.

\section{REFERENCES}

1. De Jong AL, Macdonald R, Ein S et al. (2001): Corrosive esophagitis in children: a 30-year review. Int J Pediatr Otorhinolaryngol., 57: 203-211.

2. Kochman ML, McClave SA, Boyce HW (2005): The refractory and the recurrent esophageal stricture: a definition. Gastrointestinal Endoscopy, 62 (3): 474475 . 
3. Contini S, Swarray-Deen A, Scarpignato C (2009): Oesophageal corrosive injuries in children: a forgotten social and health challenge in developing countries. Bulletin of the World Health Organization, 87: 950-954.

4. Gupta V, Wig JD, Kochhar R et al. (2009): Surgical management of gastric cicatrisation resulting from corrosive ingestion. Int J Surg., 7: 257-261.

5. Contini S, Scarpignato C (2013): Caustic injury of the upper gastrointestinal tract: A comprehensive review. World J Gastroenterol., 19 (25): 3918-3930.

6. Singhal, S, Kar P (2007): Management of acid-and alkali-induced esophageal strictures in 79 adults by endoscopic dilation: 8-years' experience in New Delhi. Dysphagia, 22(2): 130-134.

7. Akman M, Akbal H, Emir H et al. (2000): The effects of sucralfate and lective intestinal decontamination on bacterial translocation. Pediatr Surg Int., 16: 91-93.

8. Kluger Y, Ishay OB, Sartelli M et al. (2015). Caustic ingestion management: world society of emergency surgery preliminary survey of expert opinion. World Journal of Emergency Surgery, 10 (1): 48-55.

9. Tarek S, Eskander A, Ghobrial C et al. (2019): Children with corrosive strictures : A single-centre vast experience. World J Gastroenterol., 25 (7): 870-879.

10. Yalçın O, Aygün A (2019). Assessment of Unavoidable Corrosive Substance Ingestion in Children. Middle Black Sea. Journal of Health Science, 5 (1): 6-10.

11.Follent AM, Rumbach ÃAF, Ward EC et al. (2017): Speech-language Pathology in Acute Pediatric Chemical or Button Battery Ingestion Injury. Journal of
Pediatric Gastroenterology and Nutrition, 64 (1): 4246.

12. Temiz A, Oguzkurt P, Ezer SS et al. (2012): Predictability of outcome of caustic ingestion by esophagogastroduodenoscopy in children. World Journal of Gastroenterology, 18 (10): 1098-1103.

13. Rafeey M, Ghojazadeh M, Sheikhi S et al. (2016): Caustic ingestion in children: a systematic review and meta-analysis. Journal of Caring Sciences, 5 (3): 25158.

14. Nondela BB, Cox SG, Brink A et al. (2018): Correlation of $99 \mathrm{mTc}$ sucralfate scan and endoscopic grading in caustic oesophageal injury. Pediatric Surgery International, 34 (7): 781-788.

15.Huang YC, Ni YH, Lai HS et al. (2004): Corrosive esophagitis in children. Pediatric Surgery International, 20 (3): 207-210.

16. Tohda G, Sugawa C, Gayer C et al. (2008). Clinical evaluation and management of caustic injury in the upper gastrointestinal tract in 95 adult patients in an urban medical center. Surgical Endoscopy, 22 (4): $1119-1125$

17. Tharavej C (2018): Outcome of dilatation and predictors of failed dilatation in patients with acidinduced corrosive esophageal strictures. Surgical Endoscopy, 32 (2): 900-907.

18. Broor, S. L, Raju, G. S, Bose, P. P, Lahoti, D, Ramesh, G. N, Kumar, A, \& Sood, G. K. (1993). Long term results of endoscopic dilatation for corrosive oesophageal strictures. Gut, 34(11), 1498-1501. 